\title{
AN OVERVIEW OF MARINE ORNAMENTAL FISH BREEDING AS A POTENTIAL SUPPORT TO THE AQUARIUM TRADE AND TO THE CONSERVATION OF NATURAL FISH POPULATIONS
}

\author{
L.M. DOMÍNGUEZ \& Á.S. BOTELLA \\ Grupo de Investigación en Acuicultura, ULPGC \& ICCM, Telde, Canary Islands.
}

\begin{abstract}
The aquarium fish trade moves more than two billion live fish worldwide per year. For fresh water organisms, more than $90 \%$ of them are captive bred, but over $90 \%$ of commercial marine organisms are wild-caught. Wild-caught organisms come mainly from coral reefs and adjacent areas. Destructive collection techniques, such as cyanide, quinaldine, even dynamite or explosives, are commonly used. These techniques not only affect the target fish but causes terrible damages to the ecosystems and the reef habitat itself, as well as coral and crustacean bleaching. This damage has not been assessed globally, but locally, where populations have been overharvested; it has created environmental imbalances due to the selective fisheries focused on a few species, sexes or ages with high market value. A number of measures can be taken in order to reduce the environmental damage. The most important depend largely on the efforts by local governments, community groups, environmental organisations and the private sector. The final objective of these measures is to place the ornamental trade on a sustainable basis. Moreover, new research into aquaculture technology on target species with the aim of diminishing the fishing pressure on wild stocks as well as increasing the effectiveness of aquaculture facilities must be carried out. This is especially important in rural populations dependent on the aquarium trade. The present article presents an overview of the ornamental fish trade regarding the most important species involved and their situation and the harvesting effects on the ecosystem. In addition it discusses updated information on breeding protocols for some high-value marine fish species.

Keywords: Aquaculture, aquarium fish trade, marine ornamental fish.
\end{abstract}

\section{MARINE ORNAMENTAL FISH TRADE}

To a great extent, the organisation of the ornamental species trade is highly complex and dynamic, involving more than two million people worldwide, from collectors to hobbyists including governments, airlines, associations, etc.

According to the data from the Food and Agriculture Organization of the United Nations [1], the ornamental species trade represents only $0.5 \%$ of the international fish trade. However, its importance goes beyond its share in the international market. According to the FAO data, the volume of live fish export increased in value from USD 21.5 millions in 1976 to USD 315 millions in 2007 [2]. Specifically, this sector plays an important role in providing income and employment in developing countries.

The estimated annual global trade of marine organisms involves between 20 and 25 million live fishes, 12 million pieces of coral and 10 million of other invertebrates per year [2]. The ornamental trade is dominated by freshwater species; however, the increasing popularity of coral reef aquaria has become a leading trend since the late 1980s. Additionally, prices have become increasingly affordable for European and American markets [3]. The ornamental trade also supports a multimillion dollar industry in aquarium tanks, filter systems and other accessories [2]. The current economic crisis could lead to a significant drop in this business, which to date has been growing and developing rapidly.

The biggest exporters are in Southeast Asia (51\% of exports), in particular Singapore with a $20 \%$ share of the market. Europe accounts for 29\%, North America 4\% and South America 6\%; the 
biggest importers are United States of America (USA), Japan and some European countries, such as Germany, the Netherlands, and Italy [2]. The economic crisis hit the sector from late 2008, with a significant decrease in the volume of trade and its value. The socio-economic repercussions in exporting and importing countries remain unclear, but should be important, especially for rural populations in exporting countries.

Most marine ornamental fish are harvested from the wild, while only $1-10 \%$ of species in the trade are estimated to be captive-bred [4], unlike freshwater aquaria species, for which $95 \%$ of species are currently bred in captivity [2]. It must be highlighted that nearly all tropical marine fish and invertebrates are taken from coral reefs and adjacent habitats. The reefs of South-east Asia are the most important source for the aquarium trade, and because of this, they are particularly at risk [5]. Reefs support 39\% of the world's human population living within $100 \mathrm{~km}$ of the coast [4]. They provide important resources for hundreds of millions of people through both local sustenance and commerce: food, tourism-related activities, fisheries, coastal protection and new drugs [6].

The mortality of tropical organisms prior to reaching the aquarium market (25-80\%) are associated to a range of factors, including poor or even destructive collection and husbandry practices, stress and poor shipping $[2,7,8]$. Well-managed shipping and husbandry practices based on training can help to diminish these mortality levels, as has been shown [4].

Various organisations have worked to promote conservations and to develop standard procedures to trade wild specimens, such as United Nations Environment Programme (UNEP) and Marine Aquarium Council Certification (MAC).

In 1963 the UNEP members adopted the Convention on International Trade in Endangered Species of Wild Fauna and Flora (CITES) as an international agreement between governments, in order to ensure that international trade does not threaten the survival of natural populations. Species are listed in three appendices, according to the degree of protection they need. The inclusion of species in these appendices was decided at the Conference of the Parties (CoP, regular meeting of the member states of CITES and some invited organisations as NGOs), where member states submit proposals to be discussed. To date, within the 92 fish species included in CITES (15 in Appendix I and 77 in Appendix II), there has been no ornamental fishes, except for all the seahorse species (Hippocampus).

MAC was established in 1996 and launched in late 2001. This certification, which represents the only comprehensive 'reef to retail' system, provides aquarists and consumers in general a tool to identify marine aquarium organisms that originate from managed reefs, are caught using nondestructive methods, and are handled and transported according to the best practices.

\subsection{Primary fish species in aquarium trade}

Aquarium trade data at national or international levels are compiled by various organisations focusing in different types of information (e.g. UN Comtrade database, The World Customs Organization database, the EU Export Helpdesk). Most of them do not distinguish between freshwater or marine species and the figures are related on weight, value or organism number; as a result, it is not possible to compare data from different sources. Since 2000, some institutions have worked together to establish the Global Marine Aquarium Database (GMAD) as a freely available source of information on the global aquarium industry [5]. However, its use remained unextended and it is currently unavailable. The joint use of different available databases allows estimates based on quantitative rather than qualitative data, but it cannot allow calculating net volumes of trade. Nevertheless, these data gain an impression about the relative levels of trade. The main marine fish groups traded are Pomacentridae, Acanthuridae, Balistidae, Labridae, Pomacanthidae, Chaetontidae and Syngnathidae (Table 1) 
because of their appearance, colour, robustness and long life [3]. Some data about these families follows.

\subsubsection{Pomacentridae}

This is probably the best known family among aquarists and is the most traded family (Table 1) because of their great strength, bright colour and small size. This family includes 29 genera and 380 different species [9], including damselfishes (Chrysiptera spp.) and clownfishes (anemonefishes, Amphiprion spp. and Premnas spp.). Some species of this family are cultivated on a commercial scale (Table 2). These fish are found throughout the world, with most of them living in Indo-Pacific reefs. This family presents demersal spawning carried out in pairs over a solid substrate. Cleaning eggs and other parental duties are shared between males and females, until the newborns reach $1 \mathrm{~cm}$ in length, as has been observed in the spiny chromis, Acanthochromis polyacanthus [10].

Some clownfish (anemone fish) populations were overfished in localised areas and not globally [11]. However, overfishing and coral reef bleaching, which cause the loss of anemone symbionts, may limit populations of anemone fish [12].

Clownfishes maintain a typical social unit consisting of a mature female, a mature male and several sexually immature juveniles and undergo size-dependant sex reversal according to group hierarchy [13]. Most of these species spawn all year round [14], but some studies have shown that they stop spawning in the coldest period of the year [15].

\subsubsection{Acanthuridae}

This is one of the best-known families among aquarists; it includes 5 genera and 78 species [9], including the palette surgeon fish (Paracanthurus hepatus), which is a particularly important species for marine aquariums (Table 1). To date, this species, together with the yellow tang (Zebrasoma flavescens), has been the subject of much research but is still not commercially available (Table 2). These fish are found in all warm seas, and the main exporting countries are found in Asia and the Caribbean.

These fish are usually referred to as surgeonfish due to their caudal peduncle, which is different from other families, with one or more fixed or movable spines on both sides of the body that are used to defend themselves when threatened. There is no permanent sexual dimorphism, and only sexual

Table 1: The top ten traded species of marine ornamental fishes worldwide. Data provided by GMAD (Global Marine Aquarium Database).

\begin{tabular}{ll}
\hline Pomacentridae & Abudefduf spp. \\
& Chrysiptera biocellata \\
& Chrysiptera cyanea \\
& Amphiprion bicinctus \\
& Amphiprion frenatus \\
& Amphiprion ocellaris \\
Amphiprion sebae \\
Labridae & Labroides dimidiatus \\
Chaetodontidae & Heniochus acuminatus \\
Acanthuridae & Paracanthurus hepatus \\
\hline
\end{tabular}


dichromatism has been observed during the spawning season $[9,16]$ when males show their colours to the females and swim rapidly towards the surface repeatedly, during which they spawn. They exhibit herbivore habits, grazing along the reef, keeping it clean and healthy, making this a keystone species for this ecosystem.

\subsubsection{Balistidae}

This family includes 12 genera and 40 species [9], but only a few are usually traded. In 2001, more than 8,000 individuals from two different species, clown and Picasso triggerfishes (Balistoides conspicillum and Rhinecanthus aculeatus, respectively) were traded [5]. Their representatives are distributed worldwide. They present a small, strong mouth equipped with teeth used to break the shells of crustaceans. They are known as triggerfish due to a spine located in their first dorsal fin that can be locked in an upright position, anchoring them into a crevice or hiding place and which may prevent against a predator attack. During the breeding season, males prepare nesting sites, usually with gravel, and defend them vigorously while they wait for females to arrive. Egg care is performed by both parents [17].

\subsubsection{Labridae}

This family includes 8 sub-families, 65 genera and 460 species [9]. Individuals measure from several centimetres to $2 \mathrm{~m}$ in length. Their main exporters are the countries in South-east Asia. This is the second-most widespread family around the world among the marine aquarium species. The most interesting specimens for aquarium purposes are found in tropical and subtropical areas, such as the bluestreak cleaner wrasse (Labroides dimidiatus) (Table 1).

All tropical wrasses are hermaphroditic and protogynous, showing sexual size dimorphism and often dichromatism as well [18]. They present two different spawning methods:

- In a group: females and young males (between a dozen to several hundred) swim to the surface and release eggs and sperm.

- In pairs: after a courtship, the male displays its colours, and subsequent spawning and fertilisation occur either in the water column or in nests made on seaweed, where they protect their eggs [19].

\subsubsection{Pomacanthidae}

This family presents 8 genera and 88 species [9]. These fish are considered the most beautiful in marine aquaria due to their colour and majestic appearance. They live in warm seas coral reefs at depths of usually no more than $30 \mathrm{~m}$, except for some species that live at depths of over 100 metres. Adults are usually found singly or in pairs, but sometimes they create groups for feeding, breeding or migrating. These species used to show a peaceful behaviour, makes them appropriate for communitarian aquariums, especially if the aquarium size is enough and provided with plenty of hiding spaces within the rocks. Depending on species, these fish can show territorial behaviour, however agonistic encounters were rare. They can be associated with very high prices. The most common genus in this group is Centropyge, possibly because of their small size and colourful appearance. Some species of this genus have been focused on for the purpose of captive production, such as the lemonpeel angelfish (Centropyge flavissimus) [20, 21].

\subsubsection{Chaetontidae}

This family includes 12 genera and 130 species [9]. The most important species for the aquarium trade is the longfin bannerfish, Heniochus acuminatus (Table 1). This family is mainly distributed 
from the Red Sea to the Pacific (90\% of the species), with the remaining in the Atlantic Ocean [22]. They usually swim openly on the reef, presenting different feeding habits among the species (e.g. feeding on small benthic organisms, algae or plankton). Most of these species live in shallow water, except for some species found at deep outer reef walls.

These fish usually live in groups, but in the breeding season, they form pairs defending a feeding area, and they move to offshore reef tidal currents to spawn [23].

\subsubsection{Syngnathidae}

In this family, there are 55 genera and 320 species, including seahorses and pipefishes [9]. The family presents a great variability of colours and sizes ranging from $2 \mathrm{~cm}$ to $35 \mathrm{~cm}$. The depth where they can usually be found ranges between 5 and $30 \mathrm{~m}$ depending on the species and area [24], although some species have been observed at greater depths such as the paradoxical seahorse, Hippocampus paradoxus, that lives to more than $102 \mathrm{~m}$ in the south west coast of Australia [25]. The members of this family include seahorses (Hippocampus spp.) and pipe fishes (subfamily Syngnathinae), which are distributed across the Atlantic, Pacific and Indian Oceans, mainly in temperate and tropical waters, and seadragons (weedy and leafy seadragons, Phyllopterix taeniolatus and Phycodurus eques, respectively), which are only found off Australian coasts [26]. The popularity of these species is related to their unique appearance, attractiveness and unusual reproductive behaviour: males have a brood pouch found beneath the anal fin, where females deposit their eggs, which are incubated there until birth.

The main exporters are Indonesia, Brazil and the Philippines, and the main importers are China, Japan, the USA, Singapore and Taiwan. In Europe, France, Germany, Italy and Great Britain are the most significant importers. There are currently 38 recognised seahorse species by the IUCN [27], but according to Koldewey and Martin-Smith (2010), there are at least 46 spp; all of which are currently listed in Appendix II of CITES and are included in the IUCN Red List of Threatened Species [27]. However numerous misidentifications, synonyms and even spelling mistakes have resulted in a taxonomic chaos [24].

According to the UNEP-WCMC CITES Trade Database, between 1998 and 2008, a total of 806,572 live seahorses were traded. As it is well known, seahorses are traded extensively for use in traditional Chinese medicine (95\% of total seahorse traded), aquarium fish, and as aliment [28]. Little is known about the curio trade for seahorses but, globally, large numbers are involved. While the aquarium trade, hobby market and public aquariums use fewer seahorses than the dried trade, it places heavy pressure on particular populations or species [29].

Declines in wild populations of Syngnathidae family members in general and seahorse populations in particular have occurred, predominantly in western Atlantic and Indo-Pacific waters [28-32]. One of the responsible factors for population declines is thought to be the fishing pressure for commercial trade, specially related to its use in traditional Chinese medicine, as well as by-catch in fisheries and degradation and loss of habitat [33]. In response to concerns about potential impacts of trade upon wild seahorse populations, all seahorses have been included in Appendix II of CITES (Convention for the International Trade in Endangered Species of Wild and Flora) in 2002, which was implemented in May 2004.

Trade data have shown that the lined seahorse, Hippocampus erectus, and the spotted seahorse, Hippocampus kuda, are the most commonly traded species. However, a large number of individuals are cited only as Hippocampus spp.; this fact, together with the high level of synonymy in this genus, indicates likely errors in trade data. Some species of this family are cultivated on a commercial scale (Table 2). 
Table 2: Main ornamental fish species bred in captivity.

\begin{tabular}{|c|c|c|}
\hline \multirow[t]{2}{*}{ Acanthuridae } & Zebrasoma flavescens & 1 and 2 \\
\hline & Paracanthurus hepatus & 1 and 2 \\
\hline \multirow[t]{12}{*}{ Pomacentridae } & Amphiprion ocellaris & 3 \\
\hline & Amphiprion percula & 3 \\
\hline & Amphiprion clarkia & 3 \\
\hline & Amphiprion bicinctus & 3 \\
\hline & Amphiprion frenatus & 3 \\
\hline & Amphiprion melanopus & 3 \\
\hline & Amphiprion ephippium & 3 \\
\hline & Amphiprion rubrocinctus & 3 \\
\hline & Prennas biaculeatus & 3 \\
\hline & Amphiprion sadaracinos & 3 \\
\hline & Amphiprion periderion & 3 \\
\hline & Amphiprion polymnus & 3 \\
\hline \multirow[t]{6}{*}{ Pseudochromidae } & Pseudochromis fridmani & 3 \\
\hline & Pseudochromis flavivertex & 3 \\
\hline & Pseudochromis aldabraensis & 3 \\
\hline & Pseudochromis springeri & 3 \\
\hline & Pseudochromis sankeyi & 3 \\
\hline & Pseudochromis steenei & 3 \\
\hline \multirow[t]{8}{*}{ Gobiidae } & Elacatinus oceanops & 3 \\
\hline & Elacatinus figaro & 3 \\
\hline & Gobiosoma horstii & 3 \\
\hline & Gobiosoma lousiae & 3 \\
\hline & Gobiosoma punticulatus & 3 \\
\hline & Gobiosoma multifasciatum & 3 \\
\hline & Gobiodon citrinus & 3 \\
\hline & Gobiodon okinawae & 3 \\
\hline \multirow[t]{8}{*}{ Apogonidae } & Apogon imberbis & 1 \\
\hline & Apogon notatus & 1 \\
\hline & Apogon leptacanthus & 3 \\
\hline & Apogon cianosoma & 1 \\
\hline & Sphaeramia orbicularis & 1 \\
\hline & Pterapogon kauderni & 3 \\
\hline & Apogon compressus & 3 \\
\hline & Sphaeramia nematoptera & 3 \\
\hline
\end{tabular}


Table 2: Continued

\begin{tabular}{|c|c|c|}
\hline \multirow[t]{12}{*}{ Syngnatidae } & Hippocampus kuda & 3 \\
\hline & Hippocampus ingens & 3 \\
\hline & Hippocampus subelongatus & 3 \\
\hline & Hippocampus breviceps & 3 \\
\hline & Hippocampus comes & 3 \\
\hline & Hippocampus fuscus & 3 \\
\hline & Hippocampus zosterae & 3 \\
\hline & Hippocampus abdominalis & 3 \\
\hline & Hippocampus erectus & 3 \\
\hline & Hippocampus reidi & 3 \\
\hline & Hippocampus trimaculatus & 3 \\
\hline & Hippocampus hippocampus & 1 \\
\hline \multirow[t]{2}{*}{ Blenniidae } & Meiacanthus ovalaunensis & 3 \\
\hline & Meiacanthus nigrolineatus & 3 \\
\hline Pomacanthidae & Centropyge sp. & 1 \\
\hline \multirow[t]{4}{*}{ Labridae } & Thalasoma bifasciatum & 1 \\
\hline & Thalasoma cupido & 1 \\
\hline & Labroides dimidiatus & 1 \\
\hline & Halichoeres maculipinna & 1 \\
\hline \multirow[t]{2}{*}{ Plesiopidae } & Calloplesiops altivelis & 3 \\
\hline & Pareques accuminatus & 1 \\
\hline \multirow[t]{2}{*}{ Scianidaea } & Pareques umbrosus & 1 \\
\hline & Equetus lanceolatus & 1 \\
\hline
\end{tabular}

1. Subject of research.

2. Captive-raised, from wild captured post-larval stage.

3. Commercially available.

\section{WILD-CAUGHT ANIMALS AND THE IMPACT ON THE ECOSYSTEM}

The fact that more than $90 \%$ of marine traded species are currently stocked with wild-caught organisms, mostly from coral reefs or adjacent areas, raised concerns about the effects of this industry on coral reef habitats and their inhabitants. Although reefs cover less than $0.25 \%$ of the marine environment, they are considered 'the rainforest of the seas' [34], because of their high biodiversity. They are considered the most biologically and productive ecosystems of the world, and support over 4,000 species of fish (which represent a third of the total marine fish species), approximately 800 species of coral [35] and a great number of other invertebrates. Additionally, a large number of species use these ecosystems as reproduction or husbandry areas. According to Wilkinson [36], 20\% of the world's coral reefs have been effectively destroyed and show no immediate prospects of recovery. 
The threats affecting coral reefs are large. Among them are the ornamental fisheries, reef fish food trade, the jewellery and curios trade, construction material, traditional medicines and pharmaceuticals [37]. Moreover, destructive fishing techniques, such as the use of dynamite, sodium cyanide, or quinaldine, are often used to stun and catch ornamental species [38], promoting severe and longterm damage not only to target species but also to the surrounding habitat. Cyanide fishing is illegal in most countries; however, the poor law enforcement capabilities make its eradication nearly impossible [4]. Quinaldine is allowed in some areas [39]. The effect of these harmful chemicals on the reef habitat still remains unknown. More efforts in producer countries are needed to change their policies, promote awareness and regulate the importation, distribution and use of cyanide. Estimation of the use of these destructive techniques is difficult to obtain due to the clandestine nature of some of these practices. Other collection techniques, such as dynamite and explosives, are also commonly used for food fishing. During collection for trade, many more species than just the target species may be damaged, broken off or killed. All of these methods cause severe damage to populations of organisms and also the destruction of vast areas of the coral reef habitat itself [40]. Additionally, these practices have been reported to cause coral and crustacean bleaching in different degrees depending on the dose used [41, 42]. Obviously, these practices must be prevented, and other collection methods with minimal impacts on coral reefs must be promoted. Some collection techniques or devices, such as hand nets, tubular nets, lines with barbless hooks or specially designed devices for collecting particular species, as 'pana', 'kapandra' or 'hookak' has been already used in Philippines, Indonesia, Australia, Sri Lanka, Hawaii and the Pacific [4].

While a large diversity of species is demanded for the aquarium trade, a significant part of the trade tends to be characterised by extremely selective harvesting and focuses on a few species with high market value. For example, most exported fishes from Hawaii belong to five species: the flame angelfish (Centropyge loricula), the potter's angelfish (Centropyge potteri), the yellow tang ( $Z$. flavescens), the chevron tang (Ctenochaetus hawaiiensis), and the Achilles surgeonfish (Acanthurus achilles)[4].

Additionally, over-harvesting of organisms known to be fish cleaners, such as gobies (Gobiosoma spp.) and wrasses (Labroides spp.), can also negatively affect the ecology of reef fishes, especially for members of symbiotic relationships. For example, more than 20,000 cleaner wrasses are exported annually from Sri Lanka [43]. These species play a role in reef health, removing parasites and other materials, such as mucus or dead tissues. The impacts of their exploitation remain unknown.

Another issue of concern is the selective collection of juveniles and males due to their distinctive colouration [4]. This is the case for the French angelfish (Pomacanthus paru) and the neon damselfish (Neoglyphidodon oxyodon), in which juveniles are more attractive than adult conspecifics. The same is true for male mandarin fish (Synchiropus splendidus), the bird wrasse (Ghomphosus varius) and the sapphire devil (Chrysiptera cyanea). These selective fisheries may lead to imbalanced populations and ultimately affect recruitment and reproduction.

A special case is the Banggai cardinalfish (Pterapogon kauderni), an endemic species with a much localised distribution, restricted to shallow waters of the Banggai islands, a $10000-\mathrm{km}^{2}$ area in Sulawesi, Indonesia. This species is usually found in sandy bottoms with algae (Enhalus acoroides), associated with sea urchin Diadema setosum and mangroves, in colonies of between 2 and 60 individuals around sea urchins. Biologists and conservationists have expressed concern about the impact of their collection, not only due to their restricted distribution but also because of the low fecundity and high energy invested in parental care (mouth brooder), as well as the increasing demand for this species. This fishery has a negative impact on its targeted populations, even when fished with environmentally friendly techniques [44]. The inclusion of this species in any of the CITES Appendixes 
was rejected by the Commission in 2007 during the 14th CoP; however, the promotion of breeding programs was encouraged [2].

To a great extent, the effects of collecting fish for the aquarium trade on ecosystems are still unknown, despite the increasing concern. Most traders argue that these activities have no negative effects on reef populations. This concept was supported by some studies, i.e. the work carried out over four years in the Cook Islands [45] showing the sustainability of the ornamental fisheries in this area. This may be the case for small fisheries in comparison to available resource. However, the clarion angelfish (Holacanthus clarionensis) in the Revillagigedo Archipelago, where in some areas its population has decreased by up to $95 \%$ due to overfishing (some of it illegal) [46]. One systematic study on this subject carried out in Hawaii [47] reported that eight of the ten most traded species showed declines in abundance at harvesting areas relative to control areas.

In general, fish species with narrow geographical ranges can be the most vulnerable to exploitation, but also depending on the abundance. Some biological factors, such as behaviour, parental care, fecundity, and the rate and frequency of recruitment, have a significant impact on the species recovery.

Other authors compare the effects of the fish collection for ornamental trade (70-100 tonnes) with the food fish harvest (100 million tonnes) or even by-catch (17 million tonnes, [48]) or compare the major ecosystems threats such as coral bleaching or forest clearance [49]. Although the collection of ornamental fish from coral reefs has been largely recognised as having potential effects in coral degradation and decline of natural populations, the extent of the activity has not been quantified and evaluated.

\section{MARINE ORNAMENTAL AQUACULTURE}

The high demand, increasing regulations and the conservation concerns related to the marine ornamental market are factors that lead to the interest in promoting aquaculture activities for marine ornamental species. Breeding marine ornamental fish can not only provide an alternative supply for the market but also furnish new information on the reproductive biology and life history of these species, which is critical to understanding the response of natural stocks to anthropogenic effects [50].

The UNEP World Conservation Monitoring Centre Report on the Global Trade in Marine Ornamental Species (2003) [50] reported that 69 fish species associated with captive breeding, in sharp contrast with the Marine Fish Breeding Records (MFBR), which reported 575 species, of which 211 were recorded as being bred and grown to the juvenile stage and beyond [51]. This MFBR registry is a comprehensive database containing data from different sources, such as the European Association [52, 53], the Associations of Zoos and Aquaria (AZA, marine fish TAG survey, 1995) questionnaires, the Internet and popular as well as field-specific literature. These data showed the differences between successful ornamental fish reproduction reports and commercially available species (Table 2).

Recent advances in technology, including improvements in food for different life cycle stages, will enable more species to be cultured in the industry [54]. However, to date, successful rearing has been scientifically reported for only a few species and less than $1 \%$ of marine aquarium fish are commercially produced [1]. Successful larval rearing mainly concerns reproductive strategies and the size of newly hatched larvae. Key points in breeding these species are related to the spawning types displayed by marine ornamental fish species:

- Demersal spawners producing a small number of large demersal eggs, which give rise to fairly well-developed larvae (e.g. clownfishes, Amphiprion spp., gobies, Gobiosoma spp., and dottybacks, Pseudochromis spp.); 
- Pelagic spawners producing a large number of small-sized pelagic eggs, which give rise to small and poorly developed larvae (e.g. angelfishes, Centropyge spp. and Pomacanthus spp).

- Mouth breeders incubating the egg clutch in their mouth, generally carried out by the male (e.g. cardinalfishes, Apogon spp., and Pterapogon kauderni).

The majority of marine ornamental fish species cultured in captivity (e.g. clownfishes and dottybacks, Amphiprion spp. and Pseudochromis spp., respectively) display large demersal eggs. However, some success has been achieved for pelagic spawners (e.g. the yellow tang, Z. flavescens).

Another important factor is the size of newly hatched larvae, which should be large enough to accept 'traditional' live prey types that are commonly employed in food-fish aquaculture (e.g. rotifers and newly hatched Artemia). This live prey has been widely employed to feed marine fish species, including ornamental fish, because the prey organisms are easily cultured and are commercially available [55]. However, a reduction in the range of food availability can lead to nutritional imbalances in cultured fish [56]. Newly introduced live food is being tested, for example, mysis, copepods or other zooplanktonic organisms caught in the wild or cultured [57].

The most common reasons for unsuccessful larval culture are failure at first feeding and inadequate nutritional profiles of the food $[58,59]$. Because of these reasons, the early life stage remains a critical bottleneck in marine aquaculture. Larviculture protocols for marine ornamental fish species need to be optimised, especially for commercially important species. It is important to produce organisms that can compete economically with specimens from the wild [60, 61]. Despite the zootechnical breakthroughs that have been achieved in the last few years on the larviculture of some marine ornamental fish, feasible commercial-scale protocols for the mass culture of the most valuable species are still largely lacking, despite some exceptions.

Recently, companies have started marketing and selling captive-raised fish, which are captured as post-larvae from the wild and grown to market size in captivity [62]. This system is based on the principle that most marine reef fish species have a pelagic larval stage in their life cycles before returning to their 'original' reef habitat. However, during settlement, more than $95 \%$ of post-larvae disappear due to natural causes. Collecting a small percentage of these post-larvae before they are lost due to the high level of natural mortality represents a new exploitable marine resource, while helping to ensure the sustainability of coral reef ecosystems. Post-larval collection for aquaculture is certainly not the solution to the problem of overexploitation of demersal species, but it is, nevertheless, a path worth exploring, not only for developing an innovative and sustainable type of aquaculture but also to support restocking actions based on the grow-out of post-larvae until later stage and their subsequent release to the wild [63]. Moreover, this release to the wild could also be promoted to benefit collectors and decrease fishing pressure.

\subsection{Primary fish farmed species in aquarium trade}

The main families bred for aquarium purposes are Pomacentridae, Pseudochromidae, Gobiidae, Apogonidae, and Syngnathidae (Table 2). Other species from different families are currently the topic of research efforts. The present article reviews the available rearing protocols for the main fish species bred for the marine aquarium trade.

\subsubsection{Pomacentridae}

These were the first marine ornamental fishes to be cultured, but considering their importance in the aquarium trade (it represents almost half of the traded species, Table 1), a great amount of research is still being focused on breeding these fishes. This family includes damselfishes (Chrysiptera spp.) 
and clownfishes (Amphiprion and Premnas spp.), which are perhaps the most famous species in marine aquaria. Although the reproductive behaviour of damselfishes has been described for some time [15], most available information is related to clownfishes [64-66]. Some of the species of this family are commercially available, such as Amphiprion ocellaris, A. melanopus, A. frenatus, A. percula, and Premnas biaculeatus (Table 2). A description on rearing techniques for clownfishes follows.

The starting point for this process is to establish a healthy broodstock: tank-reared young fish (from 9 to 18 months), which are already adapted to captivity and are pathogen-free are the best candidates for broodstock. Protandrous hermaphroditism as well as the presence of amphisexual gonads in juveniles has been documented for most clownfishes species [65-68]. Matching broodstock colour, size and behaviour are the primary criteria [65]. The best procedure is to select animals of 4-6 cm in length and stock them in a tank. Routine observations are very important to select successful spawning pairs; depending on the species, approximately three months to more than one year are needed to initiate spawning. When pairs are selected, they should be stocked separately in tanks. The tank habitat is also important. In the wild, these fish use live anemones as a protective habitat and spawning substrate, but in captive conditions, it is better to substitute these invertebrates with an artificial substrate, such as flowerpots or PVC pipes [65], which are easy to be removed before larval hatching.

Water quality is also an important factor. Stable physical-chemical conditions are needed; the water temperature should be around $28^{\circ} \mathrm{C}$, with a $\mathrm{pH}$ of 8.2 , a salinity of 34-35 ppt and a photoperiod of $14 \mathrm{~h}$ of light. However, some authors recommend lower salinities [65].

Adverse effects of low-quality diets on broodstocks are well documented in fish [69-71]. Nevertheless, this topic continues to be one of the least studied subjects in fish nutrition and is limited to a few species [72]. When adequate environmental and nutritional conditions are provided, clownfishes spawn easily in captivity. They display cleaning behaviour before spawning $[15,66,73]$ and usually spawn at a specific hour and exhibit a special swimming pattern [65]. After spawning, males play a more dominant role, taking care of nests; mouthing eggs is a common practice [65]. Before hatching, clutches are transferred to larval tanks in commercial operations. However, the phototrophic behaviour of this species allows removing individuals from the broodstock tank. Water quality is a key factor that is easily controlled with $15 \%$ daily water exchange [73]. Larvae are fed with HUFAenriched rotifers (Brachionus plicatilis) until their 10th day (3-20 rotifers/ml). HUFA-enriched Artemia nauplii, are gradually increased from day 5 to day 7 (2-25 nauplii/ml) depending on the species, and maintained until weaning diets starts. However, there is a lack of scientific data to support these recommendations.

Damselfishes have been cultured using similar protocols to clownfish [74, 75]. The best procedure to establish a culture is to stock sexually mature damelfishes $2.3-3.5 \mathrm{~cm}$ long together [76] and to separate pairs when they are established in similar conditions to clownfish. For these species, the photoperiod and rotifer enrichment are essential for larval rearing [74].

Despite the available information, the optimisation of culture conditions to increase survival rates is still needed.

\subsubsection{Pseudochromidae}

The members of this group are actually subdivided into four subfamilies, including 16 genera and more than 70 species [76]. They are distributed from the Red Sea to the Pacific Ocean, although some species populations live exclusively in the Red Sea [77, 78]. These fishes are often associated with marine reefs at depths between 2 and $30 \mathrm{~m}$, but they usually live below a depth of five metres and at temperatures ranging between $24^{\circ} \mathrm{C}$ and $28^{\circ} \mathrm{C}$. The most famous members of this family are 
the dottybacks (Pseudochromis spp.), which are colourful but relatively aggressive and territorial fish. They are generally small, being less than $10 \mathrm{~cm}$ in length, and some can be even less than $2 \mathrm{~cm}$. Some of the species of this group are being reproduced in captivity, and are commercially available, such as the orchid dottyback (Pseudochromis fridmani), sunrise dottyback (P. flavivertix), the orange dottyback (P. aldabraensis), the Lyretail dottyback (P. steenei) and several others (Table 2). Interest in breeding and culturing these species has been increasing in the last few years due to the rise of restrictive export rules, especially for species exclusively found in the Red Sea [79].

Most of these species show sequential hermaphroditism, often showing sexual dimorphism, such that males are usually bigger than females [80]. Colour and caudal fin morphology differences have also been observed. Dottybacks lay a demersal spherical egg of approximately $2-2.5 \mathrm{~cm}(300-500$ embryos) in diameter [78, 81, 82], which is guarded by the male on the substrate until hatching [61]. Breeding pairs should be stocked in aquaria under the following conditions: water temperature around $27^{\circ} \mathrm{C}$, pH between 8 and 8.2 , salinity of $30 \mathrm{ppt}, \mathrm{NO}_{2}$ and $\mathrm{NH}_{3}$ under $0.03 \mathrm{ppm}$, and a photoperiod of $14 \mathrm{~h}$ of light, with PVC pipes placed in the tank as a spawning substrate [61].

Reproductive behaviour has been observed in pairs; before spawning, the male accompanies the female to the nest site. Imminent spawning is preceded by a distension of the female's abdomen [ 81 , $82]$ in the orchid dottyback ( $P$. fridmani) and the sunrise dottyback (P. flavivertix). The spawning event takes between one to three hours depending on the species. Then, parental care is exclusively performed by the male until hatching. If appropriate tank conditions are maintained, spawning occurs every six days. Embryo development for both species lasts $96 \mathrm{~h}$ at $27^{\circ} \mathrm{C}$ [61]. Newly hatched larvae are large $(3.6-3.8 \mathrm{~cm})$ and they start feeding the morning after hatching. During larval development, feeding is based on rotifers $(10 / \mathrm{ml})$ and enriched Artemia nauplii $(8 / \mathrm{ml})$. Higher larval survival rates $(39 \%)$ were observed using enriched live prey [61]. Despite these encouraging results, further research is needed to improve the production of these species.

\subsubsection{Gobiidae}

The family Gobiidae is one of the largest families of fish, with more than 2,000 species in more than 200 genera $[15,83]$. Gobies live primarily in shallow marine habitats, including tide pools, coral reefs, and seagrass meadows, but they are also present in brackish water and freshwater environments, such as rivers or lakes. Most gobies are relatively small, typically less than $10 \mathrm{~cm}$, and some of them can be less than $1 \mathrm{~cm}$, such as some species of the genera Trimmaton and Pandaka. Most gobies feed on small invertebrates, although some of the larger species eat other fish, and a few eat planktonic algae. Symbiotic relationships have been reported with shrimps or fishes, such as Elacatinus spp.

Some of the members of this family are important as food in Ukrainian and in Italian fish markets. As aquarium fish they are of particular interest because of their colourful appearance, habits and peaceful behaviour in the tank [84]. Moreover, some of them have cleaner habits (e.g. cleaner gobies such as the bumblebee gobies of the genus Brachygobius), which is useful for ectoparasite control [85]. They pick parasites and other debris from the body and gills of larger fish, establishing a cleaning station where other fish will gather to be cleaned. Several species have been spawned in captivity [15], and some of them are commercially produced, such as Elacatinus spp., Gobiosoma spp. and Gobiodon spp. (Table 2).

Broodstock can be easily maintained in tanks with conditions of $25^{\circ} \mathrm{C}, 30 \mathrm{ppt}$ salinity, a pH of 8.2 and a photoperiod of $13 \mathrm{~h}$ light: $11 \mathrm{~h}$ dark [86]. They feed on a wide variety of food including flake foods, frozen enriched Artemia, mixtures of finely chopped clams, shrimp, squid, fish, or formulated food (e.g. fresh seafood, vegetables, marine algae, salmon starter, and a multivitamin premix with unflavoured gelatin). Pre-spawning pairs are identified by male behaviour, consisting of cleaning the 
selected area. Gobies lay from 10 to a few hundred eggs depending on the species. They spawn in small caves, where they attach their eggs to a substrate; a short length of PVC pipe is placed on the bottom of the tank to serve as a spawning substratum. Eggs are adhered to the inside of the pipe by the female and fertilised by the male, who usually takes care of the eggs until hatching. Hatching usually occurs in 3-7 days depending on the species and temperature [87]. Goby eggs are considered ready to hatch when the eyes become fully pigmented and the yolk sacs are no longer visible. Before hatching, the PVC tube is usually removed to a larval rearing tank provided with aeration and similar physical-chemical water conditions.

Most gobiids reached metamorphosis around day 30 post-hatch [86, 88], although some species, such as the red headed goby (Tigrigobius puncticulatum) and the masked goby (Coryphopterus personatus), can take 50-60 days [79]. The larvae are born transparent, developing their colouration during the metamorphosis period. Larvae have been cultured using green water techniques [88-90], with newly hatched Artemia introduced about 15 days after larval hatching. Olivotto et al. [86] reported a higher survival rates (50\%) using naked ciliates of Euplotes sp. and small rotifers (Brachionus rotundiformes). After this point, dry food may be introduced [87] until the fish reaching adult size. Despite these studies, information regarding culture optimisation is still needed, especially regarding larval development.

\subsubsection{Apogonidae}

This family includes 22 genera and 207 species [81], but, their taxonomic composition has not been finally determined [91]. These fishes live in fresh, brackish and marinewaters. The marine species are distributed across the Atlantic, Indian and Pacific Oceans in tropical and subtropical areas [15], where they inhabit coral reefs and lagoons. The most interesting aquarium species inhabit certain Pacific Islands, and their popularity is related to their being peaceful and colourful fish. They are generally small fish, with most species being less than $10 \mathrm{~cm}$, often brightly coloured, and they are distinguished by their separate dorsal fin and their large mouths. Apogonidae, often called cardinalfish, arenocturnal, feeding on plankton and small invertebrates. Some species are cultured in captivity, including Apogon imberbis, A. notatus, A. cianosoma, Sphaeramia orbicularis and, $P$. kauderni [92-95], and some of them are commercially produced, such as the Bangaii cardinalfish $(P$. kauderni), the ochre-striped cardinalfish (A. compressus) and the Pajama cardinalfish (S. nematoptera) (Table 2).

Mouth-brooding has been described for at least for 22 of the 23 genera; in most cases, males are in charge of the egg clutch. In most species, sexual dimorphism is not evident [96]. However, during the reproductive period, a swollen abdomen on females and a lighter pigmentation on males have been described for some species, and some differences in mouth structure have also been reported; in all cases, there are subtle differences. To establish a broodstock, in most cases, a group of 6 or more is simply set up in an aquarium, and they pair temporarily during spawning. Courtship typically begins hours before actual spawning; a pair separates themselves from the group, showing a wide variety of behaviours, including nuzzling of the abdomen, circling displays, side-by-side vibrations and flutters [95].

Spawning typically occurs during the afternoon or evening after several hours of courtship. Eggs are adhesive and attached to each other; the egg clutch contains from 40 to several hundred eggs, usually in a balloon form; egg size range from 0.24 to $4.5 \mathrm{~mm}$ in diameter, depending on the species [15] and egg colours may be white (the long-spine cadinalfish Apogon leptacanthus) or orange (the red-striped cardinalfish A. margaritophorus). Incubation periods for most cardinalfish are fairly brief, ranging from 7 (A. leptacanthus) to 10-12 days (A. margaritophorus). Hatching usually takes place inside the males' mouths, and newly hatched larval sizes range from 2 to $4 \mathrm{~mm}$, depending on 
the species. They present a more advanced development stage at hatching compared to many other fish larvae, as they have open mouths and eyes that are fully developed. Juveniles leave males' mouths when the yolk sac is completely absorbed. Little is known about their feeding regime, but the first feeding usually takes place upon hatching. Green water techniques or copepods or both can be provided for the larvae. Few studies dealing with their breeding have been published, and further research is thus essential to improve aquaculture technologies regarding these species [95].

The special case of the Banggai cardinalfish (P. kauderni) must be noted. Its reproductive biology, embryo development and larval rearing have been detailed by Vagelli [95]. A school of 15 cardinalfish were maintained in tanks of 400 litres at $25 \pm 0.5^{\circ} \mathrm{C}, 36 \mathrm{ppt}$ and subjected to a photoperiod of $12 \mathrm{~h}$ light: $12 \mathrm{~h}$ dark [96]. When females are mature, an enlarged pelvic region is observed. Courtship behaviour is displayed by females, consisting of approaching a male, separating him from the group and preparing the nest site. This behaviour lasts for several hours until egg release and the male accepts mating with the female. When most of the eggs are released, the male releases sperm and then gulps the clutch, with some eggs usually falling to the bottom. From this point, the pair defends the area, and the male stops eating until the juveniles' release. If the female has more eggs than the male parent can hold, they accept the intervention of a second male, who fertilises and incubates a portion of the eggs and participates in the defence of the area. At $25^{\circ} \mathrm{C}$, the release of juveniles takes 30 days, when juveniles show a completely reabsorbed yolk sac, and their size is approximately $8 \mathrm{~mm}$ [95]. Higher survival rates are observed when HUFA-enriched Artemia are used [97,98], and an apparent absence of specific photoperiod requirements has been observed [97]. The fry are fed with brine shrimp until two months, and after that, they can eat frozen krill. They reach sexual maturity at approximately 5 to 7 months [95].

\subsubsection{Syngnathidae}

Seahorse culture is a quite recent activity in most countries [99]. Although some enthusiasts had already bred the low-crown seahorse (Hippocampus trimaculatus) in captivity as early as 1957 in China, the first large-scale effort to breed seahorses was carried out in early 1980s in different Asian countries (China and Japan) and Australia [32]. However, these facilities had to deal with the scarce knowledge about seahorse life-history, nutritional requirements, behaviour and diseases. All these affect their success. The research effort in seahorse husbandry and breeding techniques in the last 15 years led to large-scale seahorse farms in Australia, USA and New Zealand in the early 2000s. Captive breeding techniques are available only for some species, such as Hippocampus reidi, $H$. kuda, $H$. ingens, H. subelongatus, H. fuscus, H. erectus, H. trimaculatus, H. hippocampus and H. Abdominalis (Table 2). Some of these species are commercially available, such as H. reidi, H. kuda, H. zoosterae, H. breviceps, H. barbouri, and H. comes (Table 2).

Currently there are at least 28 reported seahorse operation infrastructure in 15 different countries where many of the common and larger species of seahorses are kept and bred in captivity mainly for aquarium purposes [100]. However, despite global demand for seahorse trade, the expansion of large-scale aquaculture facilities in developed countries may be limited by the high production cost compared to the retail price. On the other hand in developing countries, limitations may be related to technical problems associated with rearing activities and diseases.

Seahorses are kept in tanks from 50 to $200 \mathrm{~L}$ at temperatures between $22^{\circ} \mathrm{C}$ and $26.6^{\circ} \mathrm{C}$, a pH between 8.2 and 8.4 and salinity between 26.5 and 29 ppt. In captivity, seahorse maintenance requires the culture of live prey, such as mysid shrimp [70, 73, 101-104]. Artemia can also be used because they are easily cultured and commercially available [77, 101, 104-107]. However, they should often be enriched to increase their nutritional value prior to feeding marine fish [108]. Seahorse pairs exhibit courtship behaviour, with daily greetings, male colour changes, as well as body contraction 
to extend their brood pouch. The males then pursue females and hook onto their tail to swim together [24]. During this process female transfers eggs to the male pouch.

For larval culture [109], a number of different live prey species have been used, including copepods, mysids, wild zooplankton [110,111], and other organisms that are more common in aquaculture, such as rotifers and Artemia nauplii, which are usually enriched [59, 112]. The first days of feeding are very important and are related to survival and growth (Otero-Ferrer, personal communication). During the first two weeks of life, larvae exhibit pelagic behaviour [59, 112-114]. After that, they switch to benthic behaviour, and benefit from the introduction of an artificial holdfast into the aquaria [115]. Survival during this period ranges from 11 to $100 \%$ for Indo-Pacific seahorse species [59, 115-118]. After three months, sex can be determined visually due to the presence of the male pouch. Courtship behaviour starts between three and four months, depending on the species.

The husbandry of the syngnathids is relatively new and will require more time to resolve different breeding problems $[119,120,121]$. Thus, little is currently known, and gaps in our knowledge of their nutritional requirements and the provision of suitable food sources have been identified as constraints to the long-term success and viability of large-scale seahorse culture [105, 122, 123, 124, $125,126,127]$.

The previous discussion covers the most important species bred for ornamental trade. However, other families are currently being researched or cultivated. These include the following.

\subsubsection{Blenniidae}

There are approximately 350 blenny species in the world, spread throughout most of the world's oceans, except in the Arctic. Most blenny species live in shallow waters along rocky shorelines; a few live in freshwater streams and rivers. In general, they reach an average length of $10 \mathrm{~cm}$ and have continuous dorsal fins and lack scales. Most species lack swim bladders or have very small swim bladders, which causes them to be bottom-dwellers. Most blennies eat small invertebrates, although some eat algae. Despite the fact that they are used as food in some areas, blennies are harvested mainly as aquarium fish. Some species belonging to the genus Meiacanthus are bred in captivity (Table 2). Blennies are hardy fish requiring adequate rockwork in the aquarium, because they spend most of their time weaving in and out of caves. When challenged, they will sally forth from these caves to defend their territory. They are fed frozen or dry foods.

In the case of forktail blenny (M. artrodorsalis), males guard a small territory, often an empty shell or a rock crevice, where the female enters only to lay eggs that stick to the substratum as they are fertilised. The male then guards the eggs and ventilates them until hatching occurs. Newly hatched larvae can be reared on rotifers and Artemia using green water techniques, but survival is higher using rotifers and wild plankton. Settlement of larvae begins after 35 days, when metamorphosis is almost complete and the fish start to turn yellow [128]. Despite the existence of these data, scientific information on these species is scarce.

\subsubsection{Pomacanthidae}

The aquarist interest in this family is based mainly on angelfishes. There has been a great effort regarding the culture of these species [15, 129], in particular, the cherub pygmy angelfish, Centropyge argi $[130,131]$ and the flame angelfish, $C$. Loricula $[132,133]$. These species are the subject of research, but they are still not commercially available (Table 2).

These species exhibit sequential protogynous hermaphroditism. Sexual dimorphism is reported for the flame angelfish, $C$. Loricula [133] with males usually being larger than females. They display pelagic spawning and spawn continuously. Broodstocks are stocked in groups of 3 to 7 individuals and are fed dried food. For C. loricula in Hawaiian waters spawning is continuous throughout the 
year. For the lemon peel angelfish, C. flavissimus, temperatures of $28^{\circ} \mathrm{C}$ and longer day lengths positively affect spawning activity $[22,134]$. Eggs are collected using traps on a tank's outlet and cultured in larval rearing tanks at $27^{\circ} \mathrm{C}, 31.3 \mathrm{ppt}$ salinity and a $\mathrm{pH}$ of 7.8 [133]. The newly hatched larva is $1.326 \pm 0.107 \mathrm{~mm}$ in length; they have a large yolk sac, representing one third of their total length. At day 3 post-hatch, their mouths and anuses are open. The main problem in rearing these species occurs at first feeding due to the small size of newly hatched larvae, making it difficult to feed them on rotifers [51]. Thus, alternative live prey must be used, such as cultured and wild copepods $[22,133]$. As with so many other species, further research is needed to optimise the larval culture of these fish.

\subsubsection{Labridae}

The aquarists' interest in this family is based mainly on wrasses from the genera Thalassoma, Bodianus, Choris and Labroides. These species are protogynous hermaphrodites, and they produce pelagic eggs daily in numbers from 30 to a few thousand per female. The eggs range in diameter from 0.45 to $1.2 \mathrm{~mm}$. Newly hatched larvae range in size from 1.1 to $2.84 \mathrm{~mm}$ depending on the species $[16,135]$. Captive spawning has been reported for a number of species, such as the blue head wrasse (Thalasoma bifasciatum), the bluestreak cleaner wrasse (L. dimidiatus), the cupid wrasse ( $T$. cupido), and the clown wrasse (Halichoeres maculipinna) [134, 136, 137], but they are still not commercially available (Table 2).

\subsubsection{Plesiopidae}

The most famous member of this family for aquaria purposes is the comet or marine betta, Calloplesiops altivelis. This species lives on coral reefs throughout the Indo-Pacific, from the Red Sea and East Africa to Tonga and the Line Islands, usually in caves and crevices along drop-offs [138]. They present nocturnal habits, hiding under ledges and in holes by day [139]. They present a distinctive pigmentation, characterised by a head and body that are brownish black with small pale blue spots; vertical and pelvic fins that are dark orange-brown, with many small blue spots; and a typical blue ringed black ocellus. The false eye of this species, which is actually the dorsal fin ocellus, confuses predators because it presents an inverted image of a fish. When alarmed, it will poke its head into a hole and expose its tail end, which mimics the head of the moray eel [140]. This species has been reared in captivity [141, 142], but it is not commercially available (Table 2). They are protogynous hermaphrodites showing an aggressive courtship. Females lay from 300 to 500 eggs that are attached together and to the substrate by sticky threads, and both parents take care of the egg clutch. The average size of newly hatched larvae is $3 \mathrm{~mm}$, and they present developed eyes and an open mouth and anus. Larvae are fed rotifers and Artemia, but higher survival rates and better growth have been reported by adding copepod nauplii [51]. Juveniles eat frozen diets three months after hatching, and their typical pigmentation appears 6 months later.

\subsubsection{Scianidaea}

This family includes approximately 270 species in 70 genera [143] and is commonly known as drums or croakers. It is a highly diverse family of predacious perciform fishes, showing considerable variability in size, such that members of the genus Stellifer are relatively small (approximately $10 \mathrm{~cm}$ ), whereas other genera, such as Sciaenops, Pogonias, and some Cynoscion, are quite large (over $1 \mathrm{~m}$ ). Their morphological diversity reflects their ecological diversity; they migrate from open ocean to freshwater systems [144], although the majority of the species are adapted for life in estuaries. Other characteristics serve to unite the family $[91,145]$ include large saccularotoliths, complex swim bladders and long dorsal fins, which are usually separated by a deep notch or rarely 
are completely separated. Some species have been spawned and raised in captivity (Table 2), such as the high-hat (Pareques accuminatus), the cubbyu (P. umbrosus), and the jackknife fish (Equetus lanceolatus) [146].

They are gonochoristic, producing pelagic eggs approximately $1 \mathrm{~mm}$ in size; hatching occurs in less than one day, with 2.5-mm long larvae being produced. Larvae are fed enriched rotifers and Artemia using green water techniques. Higher survival rates, but no growth rate differences, have been reported using copepod nauplii [147]. Growth is fairly rapid, and metamorphosis to the juvenile stage occurs $20-25$ days after hatching.

\section{CONCLUSION}

Reported data regarding ornamental trade should be viewed with caution due to their different sources, their recent application, species misidentification or export/import information gaps, as has been reported in a recent work [148] that recognised the lack of available systems to monitoring the wildlife aquarium trade in USA (one of the biggest importer countries). Despite these limitations, these data are now the only available way to examine temporal trends and changes in ornamental trade. More accurate trade data and more specific information about target species are needed to promote the ornamental trade on a sustainable basis.

Coral reefs provide important resources for millions of people, both for local populations and for global trade. These ecosystems are severely threatened by overexploitation, so public awareness of issues concerning coral reefs must be enhanced, including the collection of organisms for aquaria.

Collection of marine ornamental organisms can be one of the few ways to generate sustainable income for coastal communities in many tropical and subtropical countries. Thus, governments and local communities must act jointly to establish sustainable fisheries, promote the creation of marine reserves, establish quotas and size limits, and encourage monitoring policies based on the status and biological characteristics of target species. In this way, the stocks of marine ornamental fish species can be correctly managed.

Pressure on marine ornamental resources should be reduced by increasing aquaculture production to fulfil market demand. Aquaculture can provide an increasing proportion of this demand in the near future. However, it depends on the target species, the development of further research in production techniques, and the effectiveness of aquaculture facilities [149]. Lessons from freshwater aquaculture must be applied to marine culturing. Aquaculture projects should be developed in exporting countries to provide an alternative way of living in the fishing communities, to generate employment, and to create income. In this way conservation and progress will be integrated.

\section{REFERENCES}

[1] FAO State of World Fisheries and Aquaculture 2006. Food and Agriculture Organization of the United Nations, FAO Newsletters: Rome. 2007.

[2] Monticini, P. The Ornamental Fish Trade, Production and Commerce of Ornamental Fish: Technical-Managerial and Legislative Aspects. GLOBEFISH Research Programme, Vol. 102, FAO: Rome, p. 132, 2010.

[3] Olivier, K. FAO Fishery Industries Div., Rome (Italy). GLOBEFISH Research Program: The Ornamental Fish Market, FAO: Rome (Italy), p. 122, 2001.

[4] Wabnitz, C., Taylor, M., Green, E. \& Razak, T., From ocean to aquarium. Cambridge, UK. United Nations Environment Programme - World Conservation Monitoring Centre, 2003.

[5] Burke, L., Selig, E. \& Spalding, M. Reefs at Risk in Southeast Asia, World Resources Institute: Washington DC, USA, 2002. 
[6] Molina Dominguez, L. Otero Ferrer, F. \& Izquierdo López, M. Coral reefs: threats and future focusing in over-fishing, aquaculture, and educational programs. Transactions on Ecology and the Environment, Vol. 99, ed. Witpress Southampton: United Kingdom, pp. 305-312, 2006.

[7] Gasparini, J., Floeter, S., Ferreira, C. \& Sazima, I. Marine ornamental trade in Brazil. Biodiversity Conservation, 14, pp. 2883-2899, 2005. doi: http://dx.doi.org/10.1007/s10531-004-0222-1

[8] Schmidt, C. \& Kunzmann, A. Post-harvest mortality in the marine aquarium trade: A case study of an Indonesian export facility. Live Reef Fish Information Bulletin, 13, pp. 3-12, 2005.

[9] Kuiter, H \& Debelius, H. World Atlas of Marine Fishes, ed. IKAN unterwasserarchiv: Frankfurt, p. 720, 2006.

[10] Kavanagh, K.D. Larval brooding in the marine damselfish Acanthochromis polyacanthus (Pomacentridae) is correlated with highly divergent morphology, ontogeny and life-history traits. Bulletin of Marine Science, 66(2), pp. 321-337, 2000.

[11] Shuman, C, Hodgson, G. \& Ambrose, R. Population impacts of collecting sea anemones and anemonefish for the marine aquarium trade in the Philippines. Coral Reefs, 24(4), pp. 564-573, 2005. doi: http://dx.doi.org/10.1007/s00338-005-0027-z

[12] Richardson, D. Correlates of environmental variables with patterns in the distribution and abundance of two anemonefishes (Pomacentridae: Amphiprion) on an eastern Australian subtropical reef system. Environment Biology Fish, 55, pp. 255-263, 1999. doi: http://dx.doi. org/10.1023/A:1007596330476

[13] Buston, P. Size and growth modification in clown fish. Nature, 424, pp. 145-146, 2003. doi: http://dx.doi.org/10.1038/424145a

[14] Ross, R.M. Reproductive behaviour of Anemonefish, Amphiprion Melanopus of Guam. Copeia, 1978, pp. 917-938, 1978. doi: http://dx.doi.org/10.2307/1443829

[15] Thresher, R.E. Reproduction in Reef Fishes. TFH Publications, Inc. Ltd.: New Jersey, p. 399, 1984.

[16] Robertson, D. On the spawning behaviour and spawning cycles of eight surgeon fishes (Acanthuridae) from the Indo-Pacific. Environment Biology Fish, 9, pp. 193-223, 1983. doi: http://dx.doi.org/10.1007/BF00692372

[17] Kawase, H. Spawning behaviour and biparental egg care of the Crosshatch Triggerfish, Xanthichthysmento (Balistidae). Environment Biology Fish, 66, pp. 211-219, 2003. doi: http://dx.doi.org/10.1023/A:1023978722744

[18] Gloerfertt-Tarp, T. \& Kailola, P.J. Trawled fishes of southern Indonesia and Northwestern Australia, Australian Development Assistance Bureau, Australia, Directorate General of Fishes, Indonesia, and German Agency for Technical Cooperation: Federal Republic of Germany, p. 407, 1984.

[19] Debelius, H. \& Baensch, H.A. Baensch Marine Atlas, Vol. 1, Mergus Publishers of Natural History and Pet books. H. A. Baensch: Melle, Germany, p. 1210, 2005.

[20] Laidley, C., Burnell, A. \& Ostrowski, A. Captive Reproduction of Yellow Tang and Pygmy Angelfishes at the Oceanic Institute in Hawaii. Florida Sea Grant College Program, Building 803 McCarty Drive PO Box 110400 Gainsville FL 32611 USA, p. 28, 2001.

[21] Olivotto, I., Holt, S., Carnevali, O. \& Holt, G. Spawning, early development, and first feeding in the lemonpeel angelfish Centropyge flavissimus. Aquaculture, 253, pp. 270-278, 2006b. doi: http://dx.doi.org/10.1016/j.aquaculture.2004.12.009

[22] FishBase, available at http://www.fishbase.org 2012.

[23] Yabuta, S. Spawning migrations in the monogamous butterflyfish, Chaetodontrifasciatus. Ichthyological Research, 44, pp. 177-182, 1997. doi: http://dx.doi.org/10.1007/BF02678695 
[24] Otero-Ferrer, F. Seahorses in Gran Canaria Island (Spain). Ecology and Aquaculture - Combined Tools for Marine Conservation Issues. PhD Thesis. Universidad de Las Palmas de Gran Canaria: Spain, p. 323, 2012.

[25] Foster, M. \& Gommon, MF. A new seahorse (Teleostei: Syngnathidae: Hippocampus) from south-western Australia. Zootaxa, 2613, pp. 61-68, 2010.

[26] Lourie, S.A., Vincent, A.C.J. \& Hall, H.J. Seahorse: an Identification Guide to the World's Species and Their Conservation, Project Seahorse: London, 1999.

[27] IUCN, Red List of Threatened Species, available at www.redlist.org 2006.

[28] Alverson, D., Freeberg, M., Murawski, S. \& Pope, J. A Global Assessment of Fisheries Bycatch and Discards. FAO: Rome (Italy), 1994.

[29] Vincent, A.C.J. The International Trade in Seahorses, TRAFFIC International: Cambridge, U.K., p. 163, 1996.

[30] Vincent, A.C.J. Seahorse farming is not a quick fix. Newsletter of the Marine and Coastal Community Network, 4(3), p. 18, 1997.

[31] Baum, J., Meeuwig, J. \& Vincent, A. Bycatch of lined seahorses (Hippocampus erectus) in a Gulf of Mexico shrimp trawl fishery. Fish Bulletin, 101, pp. 721-731, 2003.

[32] Martin-Smith, K.M., Samolius, M.A., Meeuwig, J.J. \& Vincent, A.C.J. Collaborative development of management options for an artisanal fishery for seahorses in Central Philippines. Ocean and Coastal Man, 47, pp. 165-193, 2004. doi: http://dx.doi.org/10.1016/j.ocecoaman.2004.02.002

[33] CITES, Convention on international trade on endangered species of wild fauna and flora. Twelfth Meeting of the Conference of the Parties, Santiago de Chile (Chile), p. 46, 2002.

[34] Spalding, M, Ravilious, C. \& Green, E. World Atlas of Coral Reefs, University of California Press: Berkeley, USA, p. 404, 2001.

[35] Paulay, G. Diversity \& Distribution of Reef Organisms, Chapman \& Hall: New York, NY (USA), pp. 303-304, 1997.

[36] Wilkinson, C. Status of Coral Reefs of the World 2004, Australian Institute of Marine Science: Townsville, p. 264, 2004.

[37] Liebermann, S. \& Field, J. Global solutions to global trade impacts? Global trade and consumers choices: coral reef in crisis. Proceedings of Annual meeting of the American Association for the Advancement of the Science, San Francisco, California, pp.19-54, 2001.

[38] Sale, F.O. Coral Reef Fishes, Dynamic and Diversity in a Complex Ecosystem, Academic Press: London, pp. 391-404.

[39] Wood, E. Global advances in conservation and management of marine ornamental resources. Aquarium Sciences and Conservation, 3(1-3), pp. 66-77, 2001.

[40] Mak, K.K.W., Yanase, H. \& Renneberg, R. Cyanide fishing and cyanide detection in coral reef fish using chemical tests and biosensors. Biosensors and Bioelectronics, 20, pp. 2581-2593, 2005. doi: http://dx.doi.org/10.1016/j.bios.2004.09.015

[41] Jones, R. \& Steven, A. Effects of cyanide on corals in relation to cyanide fishing on reefs. $M a$ rine and Freshwater Research, 48, pp. 517-522, 1997. doi: http://dx.doi.org/10.1071/MF97048

[42] Jones, R., Kildea, T. \& Hoegh-Guldberg, O.PAM chlorophyll fluorometry a new in situ technique for stress assessment in scleractinian corals, used to examine the effects of cyanide from cyanide fishing. Marine Pollution Bulletin, 38, 864-874, 1999. doi: http://dx.doi.org/10.1016/ S0025-326X(98)90160-6

[43] Woods, E. \& Rajasurija, A. Sri Lanka Marine Aquarium Fishery Conservation and management issues. Marine Conservation Society and national Aquatic Resources Agency, p. 47, 1999. 
[44] Harborne, A, Church, J., Raines, P., Ridley, J., Rettie, L. \& Walker, R. The 1996 Banggai Islands Conservation Project (Central Sulawesi, Indonesia), Coral Cay Conservation: London, UK, p. 34, 1997.

[45] Bertrand, I. The aquarium fisheries in the Cook Islands. Is there a need for management? SPC Live Reef Fish Information Bulletin, 1, pp. 10-12, 1996.

[46] Almenara-Roldan, S. \& Ketchum, J.T. Forgotten islands of the Mexican Pacific. OFI Journal, 9, pp. 12-14, 1994.

[47] Tissot, B.N. Adaptive management of aquarium fish collecting in Hawaii. SPC Live Reef Fish Information Bulletin, 6, pp. 16-19, 1999.

[48] Dawes, J. Wild-caught marine species and the ornamental aquatic industry - part 2. OFI Journal, 40, pp. 6-8, 2002.

[49] Watson, I. \& Moreau, M. The ornamental fish trade in support of livelihoods. OFI Journal, 50, pp. 20-23, 2006.

[50] Holt, G.J. Research on culturing the early life history stages of marine ornamental species. Marine Ornamental species: Collection, Culture and Conservation, eds. J.C. Cato, C.L. Brown, Iowa State Press, pp. 251-254, 2003.

[51] Laterveer, M. Breeding marine fish-from fantasy to facts, can the marine fish breeding records lift the fog? Marine Ornamentals 2004 Culture Collection and Conservation, Honolulu, Hawaii, USA, p. 56, 2004.

[52] EAZA, European Association of Zoos and Aquaria, available at www.eaza.net 2002.

[53] EAZA, European Association of Zoos and Aquaria, available at www.eaza.net 2004.

[54] Tlusty, M.F. Refocusing the American lobster (Homarusamericanus) stock enhancement program. Journal Shellfish Research, 23, pp. 313-314, 2004.

[55] González, H.E., Piloto, C.Y., Chevalier, M.P. \& Rivero, N. Efectos de la Artemia enriquecida, sobre elcrecimiento delCaballito de Mar (Hippocampus erectus Perry, 1810). CIVA, pp. 1-8, 2006, available at http://www.civa2006.org.

[56] Izquierdo, M. Essential fatty acid requirements of cultured marine fish larvae. Aquaculture Nutrition, 2, pp. 183-191, 1996. doi: http://dx.doi.org/10.1111/j.1365-2095.1996.tb00058.x

[57] Herrera, A. Gómez, M., Molina, L., Otero, F. \& Packard, T. Advances in rearing techniques and analysis of nutritional quality of two mysids species present in Gran Canaria. Larvi' 09 Fish \& Shellfish larviculture symposium, European Aquaculture Society, Special Publication No. 38: Oostende, Belgium, pp.171-174, 2009.

[58] Ogawa, T. \& Brown, C. Ornamental reef fish aquaculture and collection in Hawaii. Aquarium Science Conservation 3, pp. 151-169, 2001. doi: http://dx.doi.org/10.1023/A:1011396200887

[59] Otero, F., Molina, L., Socorro, J., Herrera, R., Fernández-Palacios, H. \& Izquierdo, M. Live prey first feeding regimes for short-snouted seahorse Hippocampus hippocampus (Linnaeus, 1758) juveniles. Aquaculture Research, 41(9), pp. e8-e19, 2010. doi: http://dx.doi. org/10.1111/j.1365-2109.2010.02505.x

[60] Calado, R., Rosa, R., Morais, S., Nunes, M.L. \& Narciso, L. Growth, survival, lipid and fatty acid profile of juvenile Monaco shrimps Lysmataseticaudata fed on different diets. Aquaculture Research, 36, pp. 493-504, 2005. doi: http://dx.doi.org/10.1111/j.13652109.2005.01235.x

[61] Olivotto, I., Rollo, A., Sulpizio, R., Avella, M., Tosti, L. \& Carnevali, O. Breeding and rearing the sunrise dottyback, Pseudochromisflavivertex: The importance of live prey enrichment during larval development. Aquaculture, 255, pp. 480-487, 2006a. doi: http://dx.doi. org/10.1016/j.aquaculture.2006.01.007 
[62] Dufour, V.J., Jouvenel, J. \& Lo, Y. Collecting marine fish and invertebrate larvae: a sustainable technology. Abstracts of the First International Conference of Marine Ornamentals, Hawaii, p. 27, 1999.

[63] Delbeek, J.C. Plenums: A path toward thriving tanks. Marine Fish and Reef USA 2007 Annual, 1(9), pp. 16-22, 2006.

[64] Godwin, J. Behavioural aspects of protandrous sex change in the anemonefish, Amphprionmelanopus, and endocrine correlates. Animal Behavior, 48, pp. 551-567, 1994. doi: http:// dx.doi.org/10.1006/anbe.1994.1275

[65] Hoff, F.H. Conditioning, Spawning, and Rearing of Fish with Emphasis on Marine Clownfish, Aquaculture consultants Inc.: Amsterdam, p. 148, 1996.

[66] Wilkerson, J.D. Clownfishes. A Guide to their Captive Care, Breeding and Natural History, ed. Microcosm Ltd.: Shelburne, VT, p. 208, 1998.

[67] Fricke, H.W. \& Fricke, S. Monogamy and sex change by aggressive dominance in coral reef fish. Nature, 266(5605), pp. 830-832, 1977. doi: http://dx.doi.org/10.1038/266830a0

[68] Hattori, A. Socially controlled growth and size-dependant sex change in the anemone fish $A$. frenatus in Okinawa, Japan. Journal Ichthyology 38, pp. 165-177, 1991.

[69] Luquet, P. \& Watanabe, T. Interaction 'nutrition-reproduction' in fish. Fish Physiology Biochemical, 2(1-4), pp. 121-129, 1986. doi: http://dx.doi.org/10.1007/BF02264080

[70] Palma, J., Stockdale, J., Correia, M. \& Andrade, J.P. Growth and survival of adult long snout seahorse (Hippocampus guttulatus) using frozen diets. Aquaculture, 278, pp. 55-59, 2008. doi: http://dx.doi.org/10.1016/j.aquaculture.2008.03.019

[71] Fernández-Palacios, H. \& Izquierdo, L.M. Efectos de la dieta de los reproductores sobre la puesta. La Reproducción de los peces: Aspectos básicos y sus Aplicaciones en Acuicultura, eds. M.A. Carrillo Estévez, Publicaciones Científicas y Tecnológicas de la Fundación Observatorio Español de Acuicultura: Aquaculture, pp. 337-380, 2009.

[72] Izquierdo, M.S., Tandler, A, Salhi, M. \& Kolkovsky, S. Influence of dietary polar lipids' quantity and quality on ingestion and assimilation of labelled fatty acids by larval gilthead seabream. Aquaculture Nutrition, 7, pp. 153-160,2001. doi: http://dx.doi.org/10.1046/j.1365-2095.2001.00165.x

[73] Olivotto, I., Buttino, I., Borroni, M., Piccinetti, C.C., Malzone, M.G. \& Carnevali, O. The use of the Mediterranean calanoid copepod Centropages typicus in Yellowtail clownfish (Amphiprion clarkii) larviculture. Aquaculture, 284(1-4), pp. 211-216, 2008. doi: http://dx.doi. org/10.1016/j.aquaculture.2008.07.057

[74] Olivotto, I., Cardinali, M., Barbasresi, L. \& Carnevali, O. Coral reef fish breeding: the secret of each species. Aquaculture 224, pp. 69-78, 2003. doi: http://dx.doi.org/10.1016/S00448486(03)00207-2

[75] Olivotto, I, Yasumasu, J., Gioachini, G., Maradonna, F., Cionna, C. \& Carnevali, O. Cloning and expression of High Choriolytic enzyme, a component of the hatching enzyme system, during embryonic development of the marine ornamental teleost. Chysipteraparasema Marine Biology, 145, pp. 1235-1241, 2004. doi: http://dx.doi.org/10.1007/s00227-004-1404-9

[76] Gill, A.C. Revision of the Indo-Pacific dottyback fish subfamily Pseudochrominae (Perciformes: Pseudochromidae). Smithiana Monograph, 1, iii + 1-214, pp. 1-12, 2004.

[77] Michael, S.W. An aquarist's guide to the dottybacks. Part I \& II. FAMA, Oct 1990, pp.8-15; Nov 90, 145, pp.16-24, 1990.

[78] Moe, M.A. Breeding the Orchid dottyback, Pseudochromisfridmani, an Aquarist's Journal, Green Turtle Publication: Islmorada, FL, p. 25.

[79] Gardner, T.R. Commercial breeding of the dottybacks. Seascope, 14, pp. 1-2, 1997. 
[80] Springer V., Lavett Smith, C. \& Thomas, H. Anisochromisstraussi, New species of Protogynous Hermaphroditic Fish, and Synonymy of Anisochromidae, Pseudoplesiopidae and Pseudochromidae, Fraser Smithsonian Contributions to Zoology, number 252. Editorial Smithsonian Institution Press: Washington, 1977.

[81] Brons, R. Nachzucht von. Pseudochromisfridmani and P. flavivertex. DATZ, 1(95), p. 7, 1995.

[82] Brons, R. Reproduction and captive breeding of two red sea dottybacks: Pseudochromisfridmani and P. flavivertex. Freshwater and Marine Aquarium, 19(6), pp. 48-62, 1996.

[83] Van Tassell, J.L. Phylogenetic Relationship of the Gobiids Genus Gobiosoma with Comments on their Relationship to other Genera in the Tribe Gobiosomini, PhD dissertation submitted to the City University of New York, p. 28, 1998.

[84] Burgess, W.E., Herbert, R.A. \& Hunziker, R.E. Atlas of Marine Aquarium Fishes, 2nd edn., TFH Publications: California, p. 348, 1990.

[85] Cowell, L., Watanabe, W.O., William, D.H., Grover, J.J. \& Shenker, J.M. Use of the tropical cleaner fish to control the ectoparasite Neobenedemiamelleni (Monogena, Capsalidae) on seawater-cultured Florida red Tilapia. Aquaculture, 113, pp. 189-200, 1993. doi: http:// dx.doi.org/10.1016/0044-8486(93)90473-C

[86] Olivotto, I., Zenobi, A., Rollo, A., Migliarini, B., Avella, M. \& Carnevali, O. Breeding rearing and feeding studies in the cleaner goby Gobiosoma evelynae. Aquaculture, 250, pp. 175-182, 2005. doi: http://dx.doi.org/10.1016/j.aquaculture.2005.02.057

[87] Gardner, T \& Van Tassell, J. A system for laboratory of commercial culture of gobiid fishes. SeaScope, 18, 2001.

[88] Van Tassell, J.L. \& Delventhal, N. Breeding of the American Seven-spined Gobies (Neon Gobies). Advanced Aquarist On line Magazine, 2, p. 22, 2003.

[89] Gardner, T.Breeding Gobiosoma for research (2000). Proceedings of ASIH - American Society of Ichthyology and Herpetology (ASIH) meetings, La Paz, Mexico, pp. 12-24, 2003.

[90] Hoff, F.H \& Snell, T.W. Plankton Culture Manual,3rd edn., ed. Florida AquaFarms, Inc.: Dade City, FL, 1987.

[91] Prokofiev, A.M. A new genus of cardinalfishes (Perciformes: Apogonidae) from the south China sea, with a discussion of the relationships between the families Apogonidae and Kurtidae. Journal Ichthyology, 46(4), pp. 279-291, 2006. doi: http://dx.doi.org/10.1134/S0032945206040011

[92] Garnaud, J. Notes partielles sur la reproduction de A. imberbis. La Terre et la vie, 1, pp. 39-42, 1950.

[93] Nakahara, K. On the spawning behaviour of a cardinal fish A. NotatusMam. Fac Fish, Kagoshima University, pp. 1114-1117, 1963.

[94] Coleman, R.K. Spawning red cardinals. Salt Water Aquarium, 2, pp. 144-148, 1966.

[95] Vagelli, A. The reproductive biology and early ontogeny of the mouthbrooding banggai cardinalfish, Pterapogon kauderni (Perciformes, Apogonidae). Environmental Biology Fishes, 56, pp. 79-92, 1999. doi: http://dx.doi.org/10.1023/A:1007514625811

[96] Fraser, T.H. Comparative osteology of the shallow water cardinal fishwith reference to the systematics and evolution of the family. Ichthyology Bulletin, 34, pp. 1-105, 1972.

[97] Vagelli, A.A. Ontogenetic shift in habitat preference by Pterapogon kauderni, a shallow water coral reef apogonid, with direct development. Copeia, 2(2), pp. 364-369, 2004. doi: http:// dx.doi.org/10.1643/CE-03-059R2

[98] Pardo Manuel De, V.I., Monti, G., Romero, J.A. \& Molina, L. Effects of photoperiod on growth and survival of larvae of Banggai cardinal fish (Pterapogon kauderni). Proceedings of Aquaculture 2007 Congress, San Antonio, Texas, USA, pp. 28-31, 2007. 
[99] Planas, M., Chamorro, A., Quintas, P. \& Vilar, A. Establishment and maintenance of threatened long-snouted seahorse, Hippocampus guttulatus, broodstock in captivity. Aquaculture, 283(1-4), pp. 19-28, 2008. doi: http://dx.doi.org/10.1016/j.aquaculture.2008.06.023

[100] Koldewey, H.J. \& Martin-Smith, K.A global review of seahorse aquaculture. Aquaculture, 302(3-4), pp. 131-152, 2010. doi: http://dx.doi.org/10.1016/j.aquaculture.2009.11.010

[101] Garrick-Maidment, N. Seahorses: Conservation and Care, Kingdom Books: UK, p. 48, 1997.

[102] Fenner, B. Pipes, horses and dragons: a real challenge. Tropical Fish Hobbyist, 46, pp. 16-29, 1998.

[103] Forteath, N. Farmed seahorses a boom to the aquarium trade. Infofish International, 3, pp. 48-50, 2000.

[104] Lin, Q., Gao, Y., Sheng, J., Chen, Q., Zhang, B. \& Lu, J. The effects of food and the sum of effective temperature on the embryonic development of the seahorse, Hippocampus kudaBleeker. Aquaculture, 262(1,2), pp. 481-492, 2006.

[105] Chang, M. \& Southgate, P.C. Effects of varying dietary fatty acid composition on growth and survival of seahorse, Hippocampus sp., juveniles. Aquarium Sciences and Conservation, 3, pp. 205-214, 2001. doi: http://dx.doi.org/10.1023/A:1011363807074

[106] Payne, M.F.\& Rippingale, R.J. Rearing West Australian seahorse, Hippocampus subelongatus, juveniles on copepod nauplii and enriched Artemia. Aquaculture, 188, pp. 353-361, 2000. doi: http://dx.doi.org/10.1016/S0044-8486(00)00349-5

[107] Woods, C.M.C. Preliminary observations on breading and rearing the seahorse Hippocampus abdominalis, Leeson, 1827 (Teleostei:Syngnathidae) in captivity. New Zealand Journal of the Marine Freshwater Research, 34, pp. 475-585, 2000. doi: http://dx.doi.org/10.1080/00288330.2000.9516950

[108] Webster, C.D. \& Lovell, R.T. Responses of striped bass larvae fed brine shrimp from different fatty acid compositions. Aquaculture, 90, pp. 49-61, 1990. doi: http://dx.doi. org/10.1016/0044-8486(90)90282-R

[109] Novelli, B. Aplicación de técnicas histológicas y osteológicas al estudio de la ontogeniaen Hippocampus sp. Máster Thesis. II International Master in Aquaculture, Universidad de las Palmas de Gran Canaria: Spain, 2012.

[110] Gardner, T. The Copepod/Artemia Trade off in the Captive Culture of Hippocampus Erectus, A Vulnerable Species in New York State, Hofstra University: Thesis. Hempstead (NY), p. 148, 2004.

[111] Kitsos, M.S., Tzomos, Th., Anagnostopoulou, L. \& Koukouras, A. Diet composition of the seahorses, Hippocampus guttulatus (Cuvier, 1829) and Hippocampus hippocampus (L., 1758) (Teleostei, Syngnathidae) in the Aegean Sea. Journal Fish Biology, 72, pp. 1259-1267, 2008. doi: http://dx.doi.org/10.1111/j.1095-8649.2007.01789.x

[112] Damerval, M., Détienne, J., Détienne, C. \& Vincent, T. Données sur l'élevage en aquarium des deux espèces d'hippocampes européens: Hippocampus hippocampus (Linné, 1758) et Hippocampus ramulosus (Leach, 1814). Bulletin de la Societé géologique de Normandie et des amis du Muséum du Havre, 90(2), pp. 45-52, 2003.

[113] Warland, T. Seahorses. How to care for your seahorses in the Marine Aquarium. South Australian seahorse Marine services. 95 pp.

[114] Choo, C.K. \& Liew, H.C. 2006. Morphological development and allometric growth patterns in the juvenile seahorse Hippocampus kuda Bleeker. Journal Fish Biology, 69, pp. 426-445, 2003. doi: http://dx.doi.org/10.1111/j.1095-8649.2006.01105.x

[115] Molina, L. Socorro, J., Herrera, R., Otero, F., Villares, P., Fernández-Palacios, H. \& Izquierdo, M. Experiencias preliminares del cultivo de Hippocampus hippocampus (Linnaeus, 1758) en Gran Canaria. Proceedings of XI CongresoNacional de Acuicultura, 24-28 September 2007. Vigo, Spain, pp. 47-54, 2007. 
[116] Reyes-Bustamante, H. \& Ortega-Salas, A.A. Cultivo del caballito de mar, Hippocampus ingens (Pisces: Syngnathidae) en condiciones artificiales. Review of Biology Tropical, 47(4), pp. 1045-1049, 1999.

[117] Jones, E.S. \& Lin, J. Effects of diet on the survival and growth of juvenile lined seahorse Hippocampus erectus. Proceedings of World Aquaculture, San Antonio, U.S.A., 2007.

[118] Wilson, M.J. \& Vincent, A. Preliminary success in closing the life cycle of exploited seahorse species, Hippocampus spp., in captivity. Aquarium Sciences and Conservation, 2, pp. 179-196, 1998. doi: http://dx.doi.org/10.1023/A:1009629130932

[119] Foster, S. \& Vincent, A. Life history and ecology of seahorses: Implications for conservation and management. Journal Fish Biology, 64, pp. 1-61, 2004. doi: http://dx.doi.org/10.1111/ j.0022-1112.2004.00429.x

[120] Hilomen-García, G. AQD's marine ornamental fish project. SEAFDEC Asian Aquaculture, 21, pp. 31-38, 1999.

[121] Giwojna, P. \& Giwojna, B. Seahorse breeding secrets: Part I. Ten common mistakes and how to avoid them. Freshwater Marine Aquarium, 1999.

[122] Binsheng, L. Research into the culture of Hippocampus. Journal of the Ocean University of Quingdao, QuingdaoHaiyangDaoxoeXoebao, 22, pp. 39-44, 1992.

[123] Segade,Á. Caracterización y modulación del color en el caballito de mar Hippocampus hippocampus. Master Thesis. II International Master in Aquaculture. Universidad de Las Palmas de Gran Canaria: Spain, p. 76, 2012.

[124] Job, S.D., Do, H.H., Meeuwig, J.J. \& Hall, H.J. Culturing the oceanic seahorse, Hippocampus kuda. Aquaculture, 214(1-4), pp. 333-341, 2002. doi: http://dx.doi.org/10.1016/S00448486(02)00063-7

[125] Woods, C.M.C. Growth of cultured seahorses (Hippocampus abdominalis) in relation to feed ration. Aquaculture International, 13(4), pp. 305-314, 2005. doi: http://dx.doi.org/10.1007/ s10499-004-3100-7

[126] Murugan, A., Dhanya, S., Sreepada, R.A., Rajagopal, S.Y, Balasubramanian, T. Breeding and mass-scale rearing of three spotted seahorse, Hippocampus trimaculatus Leach under captive conditions. Aquaculture, 290(1-2), pp. 87-96, 2009. doi: http://dx.doi.org/10.1016/j. aquaculture.2009.01.033

[127] Thangaraj, M. \& Lipton, A.P. Survival and growth of captive reared juvenile seahorse (Hippocampus kuda) fed live feeds and fishmeal. Israeli Journal of Aquaculture/Bamidgeh, 60(3), pp. 185-189, 2008.

[128] Moorhead, J.A. \& Zeng, C. Breeding of the forktail blenny Meiacanthusatrodorsalis: Broodstock management and larval rearing. Aquaculture, 318(1-2), pp. 248-252, 2011. doi: http:// dx.doi.org/10.1016/j.aquaculture.2011.05.018

[129] Sakai, Y., Karino, K., Kuwamura, T., Nakashima, Y. \& Maruo, Y. Sexually dichromatic protogynous angelfish, Centropyge ferrugata males can change back to females. Zoological Sciences, 20, pp. 627-633, 2003. doi: http://dx.doi.org/10.2108/zsj.20.627

[130] Bauer, J.A. \& Bauer, S.E. Reproductive biology of pygmy angelfishes of the genus Centropyge (Pomacanthidae). Bulletin of Marine Science, 21, pp. 495-513, 1981.

[131] Brothers, E.B. \& Thresher, R.E. Pelagic duration, dispersal and the distribution of Indo Pacific coral-reef fishes. Proceedings of the Symposium. Series Undersea Research, 3(1), pp. 53-69, 1985.

[132] Rhody, N. Growth, Yolk Utilisation, and Ontogeny of the Digestive Tract System During Early Larval Development in the Marine Ornamental Flame Angelfish (Centropyges loriculus): A Morphological and Histological Study, Stirling University: Scotland, p. 67, 2006. 
[133] De la Rosa Cano, F.J. Estudio del desarrollo larvario de dos especies asociadas a arrecifes, Pez ángel flama (Centropyges loriculus) y jurel de aleta azul (Caranx melampygus, Tesina del V Master Internacional de Acuicultura, Las Palmas deGran Canaria, España: Bristol, p. 98, 2008.

[134] Holt G.J \& Riley C.M. Laboratory spawning of coral reefs fishes: effects and temperature and photoperiod. 28th U.S. Japan Natural Resources Technical Report no. 28. pp. 33-38, 2001.

[135] Holt, G.J. Ornamental fish culture, Marine. Encyclopedia of Aquaculture, ed. R.R. Stickney, John Wiley \& Sons Inc.: pp. 610-614, 2000.

[136] Zumpe, D. Uber das ablaichenvon T. bifasciatum. Das Aquariumundterrarium, 16, pp. 86-88, 1963

[137] Meyer, K.A. Reproductive behaviour and patterns of sexuality in the Japanese labrid fish T. cupido. Japan Journal Ichtyology, 24, pp. 101-112, 1977.

[138] Kuiter, R.H. Tropical Reef-Fishes of the Western Pacific Indonesia and Adjacent Waters, Gramedia Pustaka Utama: Jakarta, 1992.

[139] Lieske, E. \& Myers, R. Collins Pocket Guide. Coral reef fishes. Indo-Pacific \& Caribbean including the Red Sea, HarperCollins Publishers: New Jersey, p. 217, 1994.

[140] McCosker, J.E. Freight posture of the plesiops fish Calloplesiops altivelis: an example of Batesian mimicry. Science, 197, pp. 400-401, 1977. doi: http://dx.doi.org/10.1126/science.197.4301.400

[141] Wassink, H. EinegelungeneZucht des Mirakelfisches, Calloplesiops altivelis (Steindachner, 1903). Aquar. Ter. Z., 3, pp. 126-130, 1990.

[142] Wassink, H. \& Brons, R.A successful cultivation of the comet. Calloplesiops altivelis. Seascope, 7, pp. 22-28, 1990.

[143] Nelson, J.S., Crossman, E.J., Espinosa-Pérez, H., Findley, L.T., Gilbert, C.R., Lea, R.N.\& Williams, J.D. Common and Specific Names of Fishes from the United States, Canada and Mexico, American Fisheries Society, Special Publication 29 Bethesda: Maryland, USA, p. 128, 2004.

[144] Chao, L.N. A basis for classifying western Atlantic Sciaenidae (Teleostei: Perciformes). NOAA Technical Report Circular, p. 415, 1978.

[145] Trewavas, E. The sciaenid fishes (croakers or drums) of the Indo-West-Pacific. Transactions of the Zoological Society of London, 33, pp. 253-541, 1977.

[146] Holt, G.J. \& Riley, C.M. Larval and juvenile development of the cubbyu Pareques umbrosus with notes on the high hat Parequesaminatus larvae. Bulletin Marine Science, 65(3), pp. 825-838, 1999.

[147] Marcus, N.H. \& Murray, M. Copepod diapause eggs: a potential source of nauplii for aquaculture. Aquaculture, 201, pp. 107-115, 2001. doi: http://dx.doi.org/10.1016/S00448486(01)00514-2

[148] Rhyne, A.L., Tlusty, M.F., Schofield, P.J., Kaufman, L., Morris, J.A. \& Bruckner, A.W. Revealing the appetite of the marine aquarium fish trade: the volume and biodiversity of fish imported into the United States. PloS one, 7(5), p. e35808, 2012.

[149] Molina, L. \& Segade, A. Aquaculture as a potential support of marine aquarium fish trade sustainability. Transactions on Ecology and the Environment, Vol. 101, ed. Wit Press Southampton: United Kingdom, pp. 15-25, 2011.

[150] Moyer, J.T. \& Bell, L.J. Reproductive behavior of the anemonefish Amphiprion clarkii at Miyake-Jima, Japan. Japanese Journal of Ichtyology, 23(1), 1976.

[151] Nelson, J.S. Fishes of the World, John Wiley \& Sons, Inc.: New York, p. 624, 1994. 